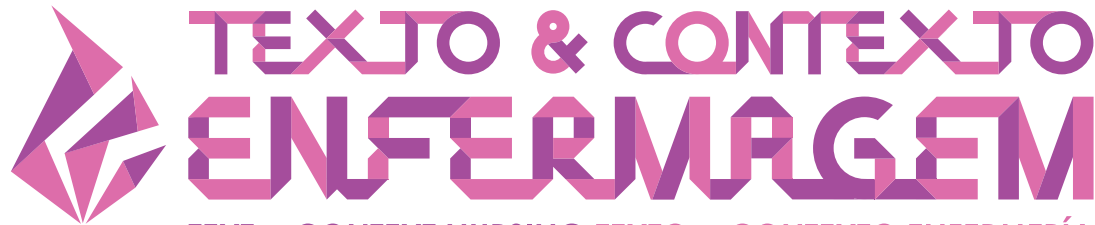

\section{CORRELATIONAL ANALYSIS BETWEEN POTENTIALLY PAINFUL PROCEDURES AND PAIN CONTROL STRATEGIES IN A NEONATAL UNIT}

\author{
Anna Caroline Leite Costa ${ }^{1}$ (D) \\ Fernanda Lopes de Araújo ${ }^{1}$ (1) \\ Delma Aurélia da Silva Simão ${ }^{1}$ \\ Mariana Bueno² \\ Juliana de Oliveira Marcatto ${ }^{1}$ \\ Bruna Figueiredo Manzo'
}

${ }^{1}$ Universidade Federal de Minas Gerais, Escola de Enfermagem. Belo Horizonte, Minas Gerais, Brasil. ${ }^{2}$ Hospital for Sick Children. Toronto, Ontario, Canada.

\begin{abstract}
Objective: to describe potentially painful procedures performed in neonates and their relation with pain relief strategies.

Method: a longitudinal correlational study, conducted from October to December 2014, with 50 neonates admitted to neonatal units of a public maternity hospital in Belo Horizonte, Minas Gerais (Brazil). Procedures were analyzed in the first two weeks of life of neonates admitted with up to three hours of life and born at the maternity hospital in which the study was conducted. Data was submitted to descriptive, comparative and correlational analyses using the Statistical Package for the Social Sciences software, adopting a significance level of $5 \%$.

Results: most newborns were male $(n=32 ; 64 \%)$, premature $(n=34 ; 69.4 \%)$ and hospitalized for having respiratory disorders $(n=45 ; 91.8 \%)$. A total of 894 painful and of 2883 potentially painful procedures related to daily care were recorded. Non-pharmacological pain relief strategies were used in $49(98 \%)$ neonates, while pharmacological strategies were used in nine $(18 \%)$. Correlational analyses revealed the difficulty of drug treatment management and the underuse of non-pharmacological strategies as adjuvant to severe pain procedures.

Conclusion: neonates underwent many potentially painful procedures, and it was found that pain relief methods are underused and that training on pain assessment and treatment is necessary in order to make these practices part of the care process.
\end{abstract}

DESCRIPTORS: Neonatology. Pain management. Acute pain. Newborn. Neonatal nursing. Physiological stress. 


\section{ANÁLISE CORRELACIONAL ENTRE PROCEDIMENTOS POTENCIALMENTE DOLOROSOS E ESTRATÉGIAS DE CONTROLE DA DOR EM UNIDADE NEONATAL}

\section{RESUMO}

Objetivos: descrever procedimentos potencialmente dolorosos realizados em neonatos e sua relação com as estratégias de alívio da dor.

Método: estudo longitudinal correlacional, realizado entre outubro e dezembro de 2014, com 50 neonatos internados em unidades neonatais de uma maternidade pública de Minas Gerais (Brasil). Foram analisados procedimentos ocorridos nas duas primeiras semanas de vida de neonatos admitidos com até três horas de vida, nascidos na maternidade na qual o estudo foi desenvolvido. Os dados foram submetidos a análises descritivas, comparativas e correlacionais por meio do software Statistical Package for the Social Sciences, adotando-se nível de significância de $5 \%$.

Resultados: a maioria dos neonatos era do sexo masculino ( $n=32 ; 64 \%)$, prematuros $(n=34 ; 69,4 \%)$ e hospitalizados por apresentarem acometimentos respiratórios $(n=45 ; 91,8 \%)$. Foram registrados 894 procedimentos dolorosos e 2883 potencialmente dolorosos relacionados ao cotidiano assistencial. As estratégias não farmacológicas de alívio da dor foram empregadas em 49 (98\%) neonatos, enquanto as farmacológicas em nove (18\%). Análises correlacionais revelaram a dificuldade de manejo do tratamento medicamentoso e a subutilização de estratégias não farmacológicas como adjuvantes de procedimentos de dor intensa.

Conclusão: os neonatos foram submetidos a muitos procedimentos potencialmente dolorosos, e constatouse a subutilização de métodos de alívio da dor e a necessidade de capacitações acerca da avaliação e tratamento da dor, a fim de tornar estas práticas parte do processo assistencial.

DESCRITORES: Neonatologia. Manejo da dor. Dor aguda. Recém-nascido. Enfermagem neonatal. Estresse fisiológico.

\section{ANÁLISIS CORRELACIONAL ENTRE LOS PROCEDIMIENTOS POTENCIALMENTE DOLOROSOS Y LAS ESTRATEGIAS DE CONTROL DEL DOLOR EN UNA UNIDAD NEONATAL}

\section{RESUMEN}

Objetivos: describir los procedimientos potencialmente dolorosos realizados en neonatos y su relación con las estrategias de alivio del dolor.

Método: estudio longitudinal correlacional, realizado entre octubre y diciembre de 2014, con 50 neonatos internados en unidades neonatales de una maternidad pública de Belo Horizonte, Minas Gerais (Brasil). Se analizaron los procedimientos implementados en las dos primeras semanas de vida de los neonatos admitidos con hasta tres horas de vida, nacidos en la maternidad donde se desarrolló el estudio. Los datos se sometieron al análisis descriptivo, comparativo y correlacional por medio del software Statistical Package for the Social Sciences, y se adoptó un nivel de significancia del $5 \%$.

Resultados: la mayoría de los neonatos era del sexo masculino $(n=32 ; 64 \%)$, prematuros $(n=34 ; 69,4 \%)$ e internados por presentar trastornos respiratorios $(n=45 ; 91,8 \%)$. Se registraron 894 procedimientos dolorosos y 2883 procedimientos potencialmente dolorosos relacionados con el cotidiano asistencial. Las estrategias no farmacológicas para el alivio del dolor se emplearon en 49 (98\%) neonatos, mientras que las farmacológicas se utilizaron en $9(18 \%)$ pacientes. Los análisis correlacionales revelaron la dificultad del manejo del tratamiento medicamentoso y la subutilización de estrategias no farmacológicas como adyuvantes de procedimientos de dolor intenso.

Conclusión: se sometió a los neonatos a muchos procedimientos potencialmente dolorosos, y se constató la subutilización de métodos de alivio del dolor y la necesidad de implementar capacitaciones acerca de la evaluación y del tratamiento del dolor, a fin de incorporar estas prácticas como parte del proceso asistencial.

DESCRIPTORES: Neonatología. Manejo del dolor. Dolor agudo. Recién nacido. Enfermería neonatal. Estrés fisiológico. 


\section{INTRODUCTION}

Pain assessment is a major challenge for care process in neonatal units. Untreated pain alters the final brain architecture and may result in immediate and late complications that manifest during development through cognitive, motor, emotional, and social changes. ${ }^{1}$

All anatomical, functional and endocrine structures needed for the propagation of nociceptive stimuli is fully developed by the $30^{\text {th }}$ Gestational Age (GA) week. However, the descending inhibitory pathway is still immature at birth, which enhances the pain experience in neonates. Still in this phase, the Central Nervous System (CNS) experiences important stages of development and maturation, in which synaptogenic processes, myelinization, neuronal migration and apoptosis occur intensely. ${ }^{2}$

Newborns (NB) admitted to neonatal units are known to undergo painful procedures. ${ }^{3}$ The decision to perform the procedures must be individualized and their implementation should collaborate with the newborn's therapeutic plan, so that the benefits of interventions overcome the risks. ${ }^{1,4}$

What is observed in the care practice of neonatal units is that the painful experience is often underestimated by professionals. ${ }^{5}$ This is due to a number of issues, since the historical-social context related to the child's insertion as an individual in society, to the lack of knowledge about the pathophysiological processes that involve the stages of transmission and interpretation of the painful stimulus. ${ }^{3,5-6}$ In practice, the result is a gap between the theoretical recommendations and the adoption of actions aimed at pain control in neonatal units.

For this reason, many studies in Brazil and abroad have been developed in order to investigate the professionals' knowledge about pain in the neonatal period, the frequency and type of painful and stressful procedures to which newborns are subjected, and the use of pain relief strategies. ${ }^{7-12}$ However, it was noticed that few of these studies establish statistical correlations among the newborn's birth profile, the frequency of such procedures and the use of pain relief strategies. ${ }^{13}$

This study aims to describe the potentially painful procedures to which neonates are submitted and their relation with the pain relief strategies employed.

\section{METHOD}

This is a longitudinal correlational study conducted in two neonatal units of a public maternity hospital, located in Belo Horizonte, Minas Gerais (MG), Brazil. Data collection took place between October and December 2014.

The sample consisted of 50 newborns, defined by convenience. The procedures performed during the first two weeks of life of neonates born at the maternity hospital and who were referred to one of the units with up to three hours of life were analyzed. Exclusion criteria were newborns transferred from other hospitals or coming from home, and patients whose data collection instrument was not completed on admission or performed improperly during the data collection phase. Inadequate filling was considered when the instrument was not filled for three or more consecutive days when the newborn was exposed to painful procedures.

During the data collection period, there were 121 hospitalizations of newborns in the investigated neonatal units and 71 patients were excluded. Of these, 36 patients were excluded due to insufficient filling of the data collection instrument. The remaining 35 were excluded because they were born elsewhere $(n=6)$; for not having the instrument filled by the professionals on admission $(n=17)$; for being referred to the units with more than three hours of life $(n=8)$; and for coming from home $(n=2)$ or from other sectors of the maternity $(n=4)$.

The data collection instrument was created by the researchers involved in the study and filled by the nursing professionals of the participating units after being trained and instructed as to the proper completion of the instrument. All employees of the three shifts of the units were trained. 
The data collection instrument was divided into three parts: the first one includes the demographic and clinical data of the newborns, obtained from the medical records (completed by the nurses); the second contains information related to the potentially painful procedures to which the NB were subjected in these units during hospitalization, which were indicated by the nursing technicians team; and the third part covers strategies employed for pain relief, also noted by nursing technicians as they were used.

Demographic and clinical data included date and time of birth, gender, route of birth, first and fifth minute Apgar score, gestational age at birth, classification according to Gestational Age (GA) (adequate, small or large), weight at birth, Cephalic Perimeter (CP) at birth and medical diagnosis at admission.

The procedures were grouped according to their nature: punctures (venous, arterial, capillary, intramuscular, subcutaneous, intradermal and central venous access), ventilatory support (intubation, extubation, airway aspiration, noninvasive mechanical ventilation), probes (gastric, enteral or bladder) and interventions in the central nervous system (lumbar or ventricular puncture). Potentially painful procedures also included the actions related to daily care: NB handling by health teams, motor or respiratory physiotherapy, noise and light, dressing changes, noninvasive examinations and device removal. ${ }^{8}$

Pain relief strategies, in turn, were grouped into pharmacological strategies, which included the use of dipyrone, paracetamol, fentanyl, morphine, midazolam and chloral hydrate; and nonpharmacological ones, which include the use of sweetened solution ( $25 \%$ glucose), non-nutritive sucking, breastfeeding, milked breast milk, skin-to-skin contact, facilitated containment, cuddling in bed, light and noise reduction and minimal handling.

Data was analyzed using the Statistical Package for the Social Sciences (SPSS) software, version 21.0 , by means of descriptive, comparative and correlational statistics, considering a significance level of $5 \%$.

For sample characterization, descriptive data analysis was performed. For categorical variables, absolute and relative frequencies were considered, and for quantitative variables, the median and percentiles 25 and 75 were used. Through the Kolmogorov-Smirnov and Shapiro-Wilk normality tests, it was identified that the variables do not have normal distribution. In addition, Spearman correlation analyses between discrete variables were performed. The total number of patients was changed according to the variables studied, due to the different response rates.

The research was developed in accordance to the determinations of Resolution 466/12, of the National Health Council of the Ministry of Health. The legal guardians of the newborns which were part of the sample agreed to participate in the study by signing the Free Informed Consent.

\section{RESULTS}

Demographic and clinical data of neonates included in this study are described in Table 1. It is noted that the sample is characterized predominantly by male NB ( $n=32 ; 64 \%)$, born through caesarean section $(n=30 ; 61.2 \%)$ and premature, with $G A<36$ weeks $(n=34 ; 69.4 \%)$. However, most had an adequate birth weight for their $\mathrm{GA}(\mathrm{n}=39 ; 79.6 \%)$. Most of the sample presented Apgar scores greater than seven in the first minute of life $(n=32 ; 65.3 \%)$, and in the fifth minute, $95.9 \%(n=47)$ the patients presented good vitality, with an Apgar greater than seven. 
Table 1 - Demographic and clinical data on admission of hospitalized neonates in two neonatal units of a public maternity hospital.

Belo Horizonte, MG, Brazil, 2018. $(n=50)$

\begin{tabular}{lcc}
\hline Parameters & N & \% Cl95\%* \\
\hline Gender & 32 & 64.0 \\
Male & 18 & 36.0 \\
Female & 50 & 100 \\
$\quad$ Total & & \\
Route of birth & 30 & 61.2 \\
$\quad$ Caesarean section & 19 & 38.8 \\
$\quad$ Vaginal & 49 & 100.0 \\
$\quad$ Total & & \\
Apgar score, first minute & 17 & 34.7 \\
$\leq 7$ & 32 & 65.3 \\
$>7$ & 49 & 100.0 \\
Total & & \\
Apgar score, fifth minute & 2 & 4.1 \\
$\leq 7$ & 47 & 95.9 \\
$>7$ & 49 & 100.0 \\
Total & & \\
Gestational age & 19 & 38.8 \\
$<34$ & 15 & 30.6 \\
$34-36$ & 15 & 30.6 \\
$\geq 37$ & 49 & 100.0 \\
Total & & \\
${ }^{*}$ Cl= confidence interval. & &
\end{tabular}

Thirty-seven neonates $(75.3 \%)$ presented more than one diagnosis of hospitalization. Most NB were hospitalized for respiratory disorders $(n=45 ; 91.8 \%)$, with newborn respiratory distress syndrome and/or transient tachypnea of the newborn being the most prevalent. In addition, 34 neonates (68\%) were diagnosed with prematurity. Acute fetal distress was the third most common disease among the neonates in the sample $(n=10 ; 20.3 \%)$. Other less frequent diagnoses were diaphragmatic hernia $(n=1 ; 2 \%)$, early sepsis $(n=2 ; 4 \%)$ and neonatal apnea $(n=1 ; 2 \%)$.

The length of stay median of the neonates in the units was 14 days, with a minimum stay of one day and a maximum of 97 days.

Table 2 describes the central tendency measures identified for the stressful and painful procedures performed in the neonates included in this study. The total number of painful procedures during the study period was 894 , including 400 punctures, 343 ventilatory support interventions, 144 probes and seven CNS interventions. Potentially painful care-related procedures predominated, with 2883 procedures in 14 days (median of 56 ) per neonate. 
Table 2 - Potentially painful procedures and pharmacological and non-pharmacological interventions employed for pain relief in each neonate in the first two weeks of life.

Belo Horizonte, MG, Brazil, 2018. ( $n=50)$

\begin{tabular}{lccc}
\hline Parameters & Median (IQ 25-75) & Minimum & Maximum \\
\hline Procedures related to daily care & $56(15.8-93.5)$ & 2 & 164 \\
Painful procedures & & & \\
Punctures & $5(3-12)$ & 0 & 29 \\
Ventilatory support & $1(0-9)$ & 0 & 63 \\
Probes & $2(1-4)$ & 0 & 11 \\
Central nervous system interventions & $0(0-0)$ & 0 & 2 \\
Pain Relief Strategies & & & 121 \\
Non-pharmacological & $56.5(20-89)$ & 0 & 11 \\
Pharmacological & $0(0-0)$ & 0 & \\
\hline
\end{tabular}

IQ: percentiles 25 and 75 .

In general, most neonates received some non-pharmacological pain relief strategy (98\%), but only 35 records of pharmacological interventions were performed in the study population (18\%).

The results obtained from the correlation of non-parametric variables analysis are presented in table 3. It was found, for example, that the lower the GA, weight and CP at birth, the more pain relief strategies the newborns receive.

Table 3 - Correlation between potentially painful procedures with birth profile and the use of pain relief strategies. Belo Horizonte, MG, Brazil, 2018. $(n=50)$

\begin{tabular}{lcc}
\hline Parameters & $\begin{array}{c}\text { Non-pharmacological } \\
\text { strategies, Rho(p) }\end{array}$ & $\begin{array}{c}\text { Pharmacological strategies, } \\
\text { Rho(p) }\end{array}$ \\
\hline Gestational age & $-.503(.000)$ & $-.435(.002)$ \\
Birth weight & $-.470(.001)$ & $-.340(.016)$ \\
Cephalic perimeter at birth & $-.396(.004)$ & $-.403(.004)$ \\
Apgar score, first minute & $-.074(.612)$ & $-.201(.167)$ \\
Apgar score, fifth minute & $.178(.220)$ & $-.202(.165)$ \\
Punctures & $.401(.004)$ & $.412(.003)$ \\
Probes & $.689(.000)$ & $.385(.006)$ \\
Ventilatory support & $.546(.000)$ & $.645(.000)$ \\
Central nervous system & $.170(.238)$ & $.330(0.19)$ \\
interventions & $.769(.000)$ & $.483(.000)$ \\
Procedures related to daily care & & \\
\hline
\end{tabular}

Spearman correlation; * $\mathrm{p}$-value $<0.05$.

Another finding evidenced by the correlation is that the greater the number of potentially painful procedures, including those related to the daily care to which the newborn is subjected, the greater the use of non-pharmacological and pharmacological strategies for pain relief.

CNS interventions, in particular, were related to the use of pharmacological strategies for pain relief. However, no correlation was found between these procedures and the use of non-pharmacological pain relief strategies. 


\section{DISCUSSION}

Of the 50 newborns included in the study, it was observed that most of them were male $(64 \%)$, born through cesarean section (61.2\%), premature (69.4\%) and with respiratory disorders (91.8\%). The prevalence of respiratory diseases in male newborns is an evidence in several studies. ${ }^{11,13-14}$ Although not an absolute indication, the cesarean section is the most common route of birth in premature births due to associations with other clinical maternal and fetal conditions. ${ }^{11}$

The neonates included in this study underwent 894 painful procedures in the first two weeks of life, which is equivalent to a median of eight painful procedures per newborn during this period. A study conducted in neonatal units in Ribeirão Preto (Brazil) found that the total number of procedures to which premature babies were exposed was 75.1 on average during 14 days. ${ }^{13}$ It is noteworthy that the interventions considered in this study as potentially painful related to daily care were presented in conjunction with the other painful procedures in the mentioned work.

Another study conducted in São Paulo (Brazil) found a median of six invasive procedures per day of hospitalization (84 procedures per newborn in 14 days). ${ }^{10}$ In Rotterdam, Netherlands, on the other hand, it was found that in 175 newborns, 21,076 procedures were performed in 14 days of hospitalization, with an average of 14.3 per day. In Paris, 42,413 procedures were recorded in 430 newborns in the same period, with an average of 16 procedures/day. ${ }^{12}$ Then, it is verified that neonates undergo a high number of procedures, especially in the first two weeks of life. ${ }^{10-14}$

The analysis of the painful procedures in the sample studied showed that the most performed interventions are ventilatory support, totaling 434 recorded events, followed by punctures with 400 recorded events, 144 probes and seven CNS interventions. The identification of this interventions profile is an important tool to enable the mobilization of actions directed to the context of each care unit. ${ }^{10.15}$

The need to treat pain in procedures associated with intense pain stimulation or evaluated as such through validated scales is well established among the health team. However, it is known that such procedures occur in a smaller proportion when compared to potentially painful procedures associated with routine care and those with less pain stimulation. Thus, in clinical practice it is more common to observe undertreatment during procedures that result in mild to moderate pain, which in turn represent the largest number of interventions. ${ }^{2,16-17}$

Regarding potentially painful procedures related to routine care, in the first two weeks of life, the sample underwent 2,883 procedures, with a median of 56 procedures per NB during the first 14 days of life. It is known that handling can be interpreted by the premature cortex as pain stimulation, when not considering a gentle touch, the neuropsychomotor organization and the willingness of the newborn for the care. Thus, there is a need to recognize the harmful potential even of simple daily actions in the context of care in neonatal units. ${ }^{18}$

The American Academy of Pediatrics recommends the adoption of pain assessment and treatment measures and the establishment of pain control through environmental, behavioral and pharmacological interventions, according to the nature of the stimulus. ${ }^{19}$ Regarding the use of pain prevention and relief strategies, 2,756 non-pharmacological interventions were recorded, with a median of 56 per neonate in the first two weeks of hospitalization.

This reveals that for potentially painful procedures related to care or which are consensually associated with mild pain stimulation, the team has indicated the adoption of non-pharmacological measures, recognizing the need for intervention. Such measures may be used in isolation, together or as an adjuvant intervention in situations where pharmacological intervention is indicated. ${ }^{20}$ 
Regarding the use of pharmacological pain relief strategies, 35 were recorded with a median of zero per neonate during this same period, which reveals the difficulty of managing drug treatment, considering the number of painful procedures to which the NB were subjected.

In general, there is no doubt about the need for analgesia during procedures consensually responsible for causing moderate to severe pain. Although the absence of analgesia in procedures such as tracheal intubation is still evident, an intervention that is known to cause severe pain, professionals usually have greater resistance to the indication of analgesics for procedures with potential for mild pain stimulation. ${ }^{5,17}$ The main obstacles to effective pain management are the teams' lack of knowledge about pain assessment strategies, the lack of alignment between assessment and treatment protocols, and the questionings about the cost-effectiveness of drug use during procedures. ${ }^{17}$

There is an interdependence between proper assessment and correct indication of pain management in the neonatal period. For the organization of therapeutic processes, it is important that pain assessment protocols are well established. Studies have shown that the team's understanding of the problem represented by pain in the context of newborn care has been improved. In addition, control measures, especially non-pharmacological, have been incorporated into the routine, minimizing the environmental and care impacts in these units. ${ }^{5,15}$

A study also points out that the involvement of parents or guardians as active partners in the entire care process makes important contributions to safety and to the prevention of adverse events such as pain, for example. Thus, it is suggested that greater family knowledge of procedures, care and risks may help health professionals to seek patient safety. ${ }^{18}$

It was shown in this study that there is a weak to moderate negative correlation among GA, birth weight and $\mathrm{CP}$ at birth using pain relief strategies. Thus, the lower the GA, weight and CP at birth, the more the newborn receives such strategies. These findings are in line with other studies, which point to prematurity and, consequently, lower weight and lower CP, as characteristics that provide a higher demand for procedures and thus, a higher use of pain relief strategies. ${ }^{11,13-14}$

The first and fifth minute Apgar scores in this study showed no statistically significant correlation with the number of procedures. Although it is a clinical finding that depressed newborns need more life support interventions, the data obtained did not show this correlation. ${ }^{21}$

The use of non-pharmacological strategies showed a strong positive correlation with potentially painful procedures related to routine care, and moderate with punctures, ventilatory support interventions and probes. Its use in CNS interventions was not statistically significant, which reinforces what has already been discussed regarding the adoption of non-pharmacological strategies during procedures that result in mild to moderate pain and points to their underuse as an adjuvant strategy. 5,17

Regarding pharmacological pain relief measures, a moderate positive correlation was found with the performance of potentially painful procedures related to daily care, punctures and ventilatory support interventions. The correlation with probes and interventions in the CNS was considered weak, which reinforces the difficulty of using pharmacological treatment, even during procedures associated with severe pain.

The weak correlation among the use of pharmacological measures and CNS procedures and probing is even more worrying because these procedures result in moderate to severe pain exposure. ${ }^{20-23}$ Studies show that nursing and medical professionals recognize that the newborn feels pain. However, there is still lack of knowledge about the assessment and adequate management of acute pain in the newborn, as well as about the undertreatment of pain (even in procedures such as peripherally inserted central catheter passage, chest drainage and intubation and orotracheal aspiration) and the erroneous indication of midazolam as an analgesic. ${ }^{21-25}$

Thus, it is evident that NB are exposed to a large number of potentially painful interventions, especially in the first weeks of life and that the most effective way for controlling pain in the neonatal 
period is to reduce exposure to such events. For this purpose, it is necessary that health professionals assess the need for the proposed procedures through multidisciplinary discussions and practices. Once the indication is agreed, it is necessary to adopt principles of minimum intervention, to adopt good practices through staff training, and to implement scientific evidence-based protocols for pain prevention and assessment by means of validated scales, apart from an appropriate therapeutic indication. Thus, the objective is to minimize pain exposure, as well as to offer appropriate treatment.

The study found the fragility of newborn records filling. However, the research team increased constant monitoring to reduce losses.

\section{CONCLUSION}

Pain may cause short- and long-term consequences for neonates and may compromise their clinical recovery and neuropsychomotor development. The results of this study showed that neonates undergo many procedures, especially those potentially painful, which reflect the gaps in daily care practices in neonatal units. In addition, there is still undertreatment of pain, whether mild, moderate or severe.

Thus, there should be an investment in the training of professionals and stimuli for care practices reflection, so that an adequate assessment of the real need to perform painful and potentially stressful procedures occurs, and the subsequent development of care protocols based on scientific evidences that include the proper treatment of the painful stimulus.

\section{REFERENCES}

1. Hatfield LA, Meyers MA, Messing TM. A systematic review of the effects of repeated painful procedures in infants: Is there a potential to mitigate future pain responsivity? J Nurs Educ and Prac [Internet]. 2013; 3(8):99-112. Available from: https://dx.doi.org/10.5430/jnep.v3n8p99

2. Lemus-Varela ML, Sola A, Golombek S, Baquero H, Borbonet D, Davila-Aliaga C, et al. Consenso sobre el abordaje diagnóstico y terapéutico del dolor y el estrés en el recién nacido. Rev Panam Salud Publica [Internet]. 2014 [cited 2018 Jun 4];36(5):348-54. Available from: https://www. scielosp.org/pdf/rpsp/v36n5/10.pdf

3. Motta GCP, Cunha MLC. Prevention and non-pharmacological management of pain in newborns. Rev Bras Enferm [Internet]. 2015 Jan-Feb [cited 2014 Jun 4];68(1):131-5. Available from: https:// dx.doi.org/10.1590/0034-7167.2015680118p

4. Fitzgerald M. What do we really know about newborn infant pain? Exp Physiol. [Internet]. 2015 [cited 2018 Jun 4];100(12):1451-7. Available from: https://doi.org/10.1113/EP085134

5. Silva GM, Figueiredo MGS, Kameo SY, Oliveira FM, dos Santos AD. Conhecimento das enfermeiras atuantes em unidade de terapia intensiva frente a dor no recém-nascido pré-termo. Rev. iberoam. Educ. invest. Enferm. [Internet]. 2015 [cited 2018 Jun 4];5(1):47-55. Available from: http://www. enfermeria21.com/revistas/aladefe/articulo/150/conhecimento-das-enfermeiras-atuantes-emunidade-de-terapia-intensiva-frente-a-dor-no-recem-nascido-pre-termo/

6. Soares ACO, Caminha MFC, Coutinho ACFP, Ventura CMU. Pain in the neonatal unit: the knowledge, attitude and practice of the nursing team. Cogitare Enferm. [Internet]. $2016 \mathrm{Apr}-$ June [cited 2018 Jun 4];21(2):1-10. Available from: https://revistas.ufpr.br/cogitare/article/ view/42897/28164

7. Costa T, Rossato LM, Bueno M, Secco IL, Sposito NPB, Harrison D, et al. Nurses' knowledge and practices regarding pain management in newborns. Rev Esc Enferm USP [Internet]. 2017 [cited 2018 Jun 4]; 51:e03210. Available from: https://dx.doi.org/10.1590/S1980-220X2016034403210 
8. Gaíva MAM, Blanco e Silva F, Azevedo FM, Rubira EA. Procedimentos dolorosos em recémnascidos prematuros em unidade terapia intensiva neonatal. Arq Ciênc Saúde [Internet]. 2014 Jan-Mar [cited 2018 June 4]; 21(1):48-54. Available from: http://repositorio-racs.famerp.br/racs_ol/ vol-21-1/ID-576-21(1)-(Jan-Mar-2014).pdf

9. Prestes AC, Balda RCX, dos Santos GMS, Rugolo LMSS, Bentlin MR, Magalhães M, et al. Painful procedures and analgesia in the NICU: what has changed in the medical perception and practice in a ten-year period? J Pediatr [Internet]. 2016 [cited 2018 June 4];92(1):88-95. Available from: https://dx.doi.org/10.1016/j.jped.2015.04.009

10. Sposito NPB, Rossato LM, Bueno M, Kimura AF, Costa T, Guedes DMB. Assessment and management of pain in newborns hospitalized in a Neonatal Intensive Care Unit: a cross-sectional study. Rev Latino-am Enfermagem [Internet]. 2017 [cited 2018 June 4];25:e2931. Available from: https://dx.doi.org/10.1590/1518-8345.1665.2931

11. Ananda KJS, Eriksson M, Boyle EM, Avila-Alvarez A, Andersen RD, Sarafidis K. Assessment of continuous pain in newborns admitted to NICUs in 18 European countries. Acta Pædiatr [Internet]. 2017 [cited 2018 June 4];106(8):1248-59. Available from: https://dx.doi.org/10.1111/apa.13810

12. Allegaert $\mathrm{K}$, Anker JN. Neonatal pain management: still in search of the Holy Grail. International. Int J Clin Pharmacol Ther [Internet]. 2016 Jul [cited 2018 June 4];54(7):514-23. Available from: https://dx.doi.org/10.5414/CP202561

13. Bonutti DP, Daré MF, Castral TC, Leite AM, Vici-Maia JA, Scochi CGS. Dimensioning of painful procedures and interventions for acute pain relief in premature infants. Rev latinoam enferm. [Internet]. 2017 [cited 2018 Jun 4];25:e2917. Available from: https://dx.doi.org/10.1590/15188345.1387.2917

14. Damian A, Waterkemper R, Paludo CA. Perfil de neonatos internados em unidade de tratamento intensivo neonatal: estudo transversal. Arq Ciênc Saúde [Internet]. 2016 Apr-Jul [citado 2018 Jun 4];23(2):100-5. Available from: https://doi.org/10.17696/2318-3691.23.2.2016.308

15. Araujo GC, Miranda JOF, dos Santos DV, de Camargo CM, Nascimento CL Sobrinho, Rosa DOS. Dor em recém-nascidos: identificação, avaliação e intervenções. Rev. Baiana Enferm. [Internet]. 2015 [cited 2018 June 4]; 29(3):261-70. Available from: http://dx.doi.org/10.18471/ rbe.v29i3.13695

16. Witt N, Coynor S, Edwards C, Bradshaw H. A Guide to Pain Assessment and Management in the Neonate. Curr Emerg Hosp Med Rep [Internet]. 2016 [cited 2018 June 4]; 4:1-10. Available from: https://dx.doi.org/10.1007/s40138-016-0089-y

17. Kraychete DC, Siqueira JTT, Garcia JBS and Specialists Group. Recommendations for the use of opioids in Brazil: Part II. Use in children and the elderly. Rev Dor [Internet]. 2014 Jan-Mar [cited 2018 June 4];15(1):65-9. Available from: https://dx.doi.org/10.5935/1806-0013.20140015

18. Sousa FCP, Montenegro LC, Goveia VR, Corrêa AR, Rocha PK, Manzo BF. Family participation in patient safety in neonatal units from the nursing perspective. Texto Contexto Enferm [Internet]. 2017 [cited 2018 Oct 4];26(3):e1180016. Available from: https://dx.doi.org/10.1590/010407072017001180016

19. American Academy of Pediatrics, Committee on Fetus and Newborn and Section on Anesthesiology and Pain Medicine. Prevention and Management of Procedural Pain in the Neonate: an update. Pediatrics [Internet]. 2016 [cited 2018 June 4];137(2):e20154271. Available from: http://pediatrics. aappublications.org/content/early/2016/01/22/peds.2015-4271

20. Jordão KR, Pinto LA, Machado LR, Costa LB, Trajano ET. Possible stressors in a neonatal intensive care unit at a university hospital. Rev Bras Ter Intensiva. [Internet]. 2016 [cited 2018 June 4];28(3):310-4. Available from: https://dx.doi.org/10.5935/0103-507X.20160041 
21. Cordeiro RA, Costa R. Non-pharmacological methods for relief of discomfort and pain in newborns: a collective nursing construction. Texto Contexto Enferm [Internet]. 2014 Jan-Mar [cited 2018 June 4];23(1):185-92. Available from: https://dx.doi.org/10.1590/S0104-07072014000100022

22. Witt N, Coynor S, Edwards C, Bradshaw H. A Guide to Pain Assessment and Management in the Neonate. Curr Emerg Hosp Med Rep [Internet]. 2016 [cited 2018 June 4];4(1):1-10. Available from: https://dx.doi.org/10.1007\%2Fs40138-016-0089-y

23. Capellini VK, Daré MF, Castral TC, Christoffel MM, Leite AM, Scochi CGS. Knowledge and attitudes of health professionals regarding pain assessment and management in neonates. Rev Eletrônica Enferm [Internet]. 2014 [cited 2018 Jul 23];16(2):361-9. Available from: https://dx.doi. org/10.5216/ree.v16i2.23611

24. Christoffel MM, Castral TC, Daré MF, Montanholi LL, Scochi CGS. Knowledge of healthcare professionals on the evaluation and treatment of neonatal pain. Rev Bras Enferm [Internet]. 2016 [cited $2018 \mathrm{Jul}$ 23];69(3):516-22. Available from: https://dx.doi.org/10.1590/0034-7167.2016690319i

25. Christoffel MM, Castral TC, Daré MF, Montanholi LL, Gomes ALM, Scochi CGS. Attitudes of healthcare professionals regarding the assessment and treatment of neonatal pain. Esc Anna Nery [Internet]. 2017 [cited 2018 Jul 23];21(1): e20170018. Available from: http://www.scielo. br/scielo.php?script=sci_arttext\&pid=S1414-81452017000100218\&lng=en\&nrm=iso\&tlng=en 


\section{NOTES}

\section{CONTRIBUTION OF AUTHORITY}

Study design: Costa ACL, Bueno M.

Data collection: Costa ACL.

Analysis and interpretation of data: Costa ACL, Araújo FL, Simão DAS, Marcatto JO, Manzo BF.

Discussion of the results: Costa ACL, Araújo FL, Simão DAS, Marcatto JO, Manzo BF.

Writing and/or critical review of content: Costa ACL, Araújo FL, Simão DAS, Marcatto JO, Manzo BF. Review and final approval of the final version: Costa ACL, Araújo FL, Simão DAS, Bueno M, Marcatto JO, Manzo BF

\section{FUNDING INFORMATION}

Conselho Nacional de Desenvolvimento Científico e Tecnológico - CNPq.

\section{ETHICS COMMITTEE IN RESEARCH}

Approved by the Ethics Committee in Research with Human Beings of the Universidade Federal de Minas Gerais and by the Ethics Committee in Research with Human Beings study field institution (Certificate of Presentation for Ethical Appreciation N. 09226613.8.0000.5149).

\section{CONFLICT OF INTERESTS}

There is no conflict of interest.

\section{HISTORICAL}

Received: August 17, 2018.

Approved: October 23, 2018.

\section{CORRESPONDENCE AUTHOR}

Fernanda Lopes de Araújo

fernanda.lopesaraujo@gmail.com 